\title{
Spontaneous plant recolonization on reclaimed post-coal mining sites in East Kalimantan, Indonesia: Native versus alien and succession progress
}

\author{
LIA HAPSARI", TRIMANTO" ${ }^{\vee v}$, SUGENG BUDIHARTA ${ }^{\text {vv }}$ \\ Purwodadi Botanic Garden, Research Center for Plant Conservation and Botanic Gardens, Indonesian Institute of Sciences. Jl. Raya Surabaya-Malang \\ km 65, Purwodadi, Pasuruan 67163, East Java, Indonesia. Tel./fax. +62-341-426046, `email: hapsari.lia@gmail.com, lia.hapsari@lipi.go.id; \\ vvtriman.bios08@gmail.com,trim006@lipi.go.id; "vvsugengbudiharta@yahoo.com; sugeng.budiharta@lipi.go.id
}

Manuscript received: 7 April 2020. Revision accepted: 14 April 2020.

\begin{abstract}
Hapsari L, Trimanto, Budiharta S. 2020. Spontaneous plant recolonization on reclaimed post-coal mining sites in East Kalimantan, Indonesia: Native versus alien and succession progress. Biodiversitas 21: 2003-2018. Comparative vegetation analyses subjected to recolonization of spontaneous plants were carried out in two post-coal mining reclamation sites, with different ages of reclamation, specifically 9 years old and 17 years old, in Bontang, East Kalimantan. This study aims to determine the spontaneous plant diversity and composition, identify the spontaneous alien plant species invasion (IAS), analyze the underlying micro-climates and soil factors and their association to the spontaneous plant recolonization, also to evaluate the succession progress. Results showed that both reclamation sites have undergone some vegetation and environmental improvements. The plant succession stage of both sites was identified at the same stage, as establishment phase of early-succession stage in transition to mid-succession stage. The spontaneous plants were comprised of two layers, i.e. (i) understories include grasses, ferns, lianas, herbs, shrubs and tree seedlings; and (ii) saplings include some of trees and small trees. Plant diversity indices on both sites were in moderate category. At understory layer, the 9-y.o. site was mostly dominated by grass Polytrias indica, whereas the 17-y.o. site was dominated by shrub Asystasia gangetica. At sapling layer, the 9-y.o. site was mostly dominated by Glochidion obscurum, whereas the 17-y.o. site was dominated by Macaranga tanarius. Dominant pioneer tree and shrub species in two reclamation sites mostly from general species component of secondary tropical forests from the families Euphorbiaceae, Phyllantaceae, Melastomaceae, Leguminosae, and Lamiaceae. It was recorded seven IAS in the 9-y.o. site, which six out of seven species were dominant. Meanwhile, in the 17-y.o. site was recorded eight IAS but only four species were dominant. Two dominant noxious weed species were also identified. Each IAS and noxious weed species has invasiveness traits that make them well-grown, successfully recolonized and invaded the reclamation site. Environmental factors include air temperature, air moisture, and light intensity; and soil conditions include $\mathrm{pH}, \mathrm{C} / \mathrm{N}$ ratio and physicochemical properties affected the variation of spontaneous plant establishment on each reclamation site. These comparative study findings may become inputs for coal mining operations management to evaluate and improve their reclamation program; such as by soil reconditions, controlling the populations of IAS, and planting more intensively of native tree species.
\end{abstract}

Keywords: Degraded land, natural plant, pioneer plant, revegetation, understory

\section{INTRODUCTION}

Open-cast or surface mining commonly practiced by commercial exploitation of coal in most countries, resulted in irreversible extensive degradation which completely modified the ecological system. The natural landscape has been disturbed and damaged, also with the destruction of biodiversity within ecosystems through the removal of natural soils, plants, animals, microbes, etc. (Mossa and James 2013; Macdonald et al. 2015). As the coal is being extracted at least soon after operations ceased, a decision must be made as to how the site with all mine spoils will be rehabilitated. Rehabilitation of the post-mining site is essential and become responsibility for all miner operations. Some related regulatory framework and policies have been proposed, ratified and enforced (Dwiki 2018; Schladweiler 2018). Rehabilitation is the term used for the progression towards the reinstatement of the original ecosystem (McDonald et al. 2016). The rehabilitation of mine spoils challenges should resemble its natural previous landforms as much as possible. However, mine spoils possess very harsh conditions for plant establishment and growth due to low organic matters, heavy metal contents and other unfavorable physicochemical characteristics (Makineci et al. 2011; Tripathi et al. 2012).

Succession is a dynamic and continuous process, which occurs gradually over time. Plant succession following the exogenous disturbances associated with surface mining is a subject of both ecological and practical interests (Makineci et al. 2011). During plant establishment at different stages of succession, recolonization of diverse plant species plays a major role in the process of soil formation, which in turn the improved soil condition will promote the plant succession. The effectiveness of ecosystem rehabilitation can be assessed based on the rate of natural or spontaneous vegetation recovery and nutrient status of the spoils. In order to reclaim the resilience of a disturbed ecosystem, it is important to restore as much as possible aspects of spontaneous vegetation (Hazarika et al. 2006; Chen et al. 2019). Therefore, the diversity of spontaneous plant recolonization on reclamation sites and how it survives needs to be studied and periodically monitored. 
Nowadays, invasive alien species (IAS) are considered as primary threat to global biodiversity, ecosystem functions, economies and human health (Early et al. 2016). It has become increasingly significant management problems in parks and reserves and frequently complicates the restoration/reclamation projects (Kabrna et al. 2013; Trimanto and Hapsari 2016, Yusuf and Arisoesilaningsih 2017). Previously and still to some extent today, alien plant species are used in reclamation, to stabilize land and quickly develop a vegetation community (Lemke et al. 2012). However, due to its noxious and invasiveness traits as well as habitat attributes the IAS are often spontaneously occurs and invades on severely disturbed landscapes such as due to surface mining, which challenging the efforts to reclaim and restore into its native forests (Lister 2010; Lemke et al. 2012; Franke 2016). Thus, awareness and proper management of the spontaneous establishment and expansion of invasive plant communities must be advocated.

A successful reclamation program attempts to accelerate the spontaneous recovery processes to reclaimed soil fertility and to enhance biological diversity. Comparative spontaneous plant succession studies on disturbed sites are providing significant insights into vegetation dynamics to ensure the success of future reclamation program (Makineci et al. 2011). Nonetheless, information about the process of spontaneous plant succession in post-coal mining reclamation sites, particularly in the tropical countries of Southeast Asia is still limited. In this present study, spontaneous plant recolonization on reclaimed post-coal mined sites with two different ages of reclamation in Bontang, East Kalimantan (Indonesia) were compared. Recently, the coal mining business in East Kalimantan was increasing sharply with total area concessions reached over 5.4 million hectares by 1,476 miner operation units in 2012. It was estimated at about 37.5 billion tonnes or $35.7 \%$ of national coal deposits available in East Kalimantan (Department of Mineral and Energy East Kalimantan, 2013). On the other hand, Borneo (incl. East Kalimantan) is also recognized for its outstanding biodiversity richness and high species endemism level (Budiharta and Meijaard 2014), thus become interesting area to study.

The objectives of this study were to assess and compare the diversity and compositional variation of spontaneous plant recolonization on post-coal mining reclamation sites with two different ages of reclamation in Bontang, East Kalimantan i.e. 9-years old and 17-years old, to identify the spontaneous alien plant species invasion, to analyze the underlying micro-climates and soil factors and their association to the spontaneous plant recolonization, and to evaluate the succession progress and effectiveness during the reclamation process on both sites. The results of this study may become inputs and technical references to coal mining operations management for a successful reclamation program on post-coal mined landscapes, particularly in Southeast Asia.

\section{MATERIALS AND METHODS}

\section{Study area}

The study area was located in Berebas Pantai, Bontang Municipality of East Kalimantan Province, Indonesia. The spontaneous plant recolonization studies were conducted in two reclaimed post-coal mining sites with different ages of reclamation: (i) Melati site, geographically positioned at $\mathrm{N}$ 00 09'.32.6" E117 16'.02.6" to N 00 09'.33.8" E117 $166^{\prime} .00 .6^{\prime \prime}$, with age of 9-years old reclamation (reclaimed on 2009) and (ii) Waste Dump I site, geographically positioned at $\mathrm{N} 00$ 09'.12.4" E117 16'.54.3" to $\mathrm{N} 00$ 09'.15.1" E117 16'.56.8", with age of 17-years old reclamation (reclaimed on 2001). In addition, two sites of pre-mining forest located surround the reclamation sites, i.e. East Block I (N 00 08'.00.6" E117 20'.02.2" to N 00 08'.26.1" E117 20'.17.3") and East Block II (N N 00 08'.13.1" E117 22'.03.9" to N 00 09'.04.9" E117 22'.00.5"); to give initial picture of previous natural floristic composition were also examined referred to Budiharta et al. (2020, data not shown) (Figure 1).

\section{Procedures \\ Sampling method and vegetation analysis}

Fieldworks were undertaken from February to March 2018. The sampling method was using purposive sampling with nested plots. Vegetation analysis was carried out subjected to spontaneous plants recolonization occurred in the sampling plots. Plots of $5 \mathrm{~m} \times 5 \mathrm{~m}$ were established to analyze the sapling layer, and nested plots of $2 \mathrm{~m} \times 2 \mathrm{~m}$ for understory layer, with 13 replications per site. Ground cover plants, shrubs and tree seedlings less than $1.5 \mathrm{~m}$ in height were considered as understories, whereas trees and small trees with more than $1.5 \mathrm{~m}$ in height and stem diameter less than $7 \mathrm{~cm}$ at breast height were categorized as saplings. The plant species, number of species and individual plants were recorded. Further, their plant habitus (viz. tree, shrub, grass, herbaceous, liana, and fern) in each plot were categorized. Actual environmental variables recorded at sampling sites include latitude, altitude, air temperature, air relative humidity (moisture) and light intensity.

\section{Soil analysis}

Soil samples with three replications per site were taken using ring soil sampling for further analysis in Soil Laboratory, Faculty of Agriculture, Mulawarman University, Samarinda, East Kalimantan. Soil samples were taken in depth of 0-20 cm, and mixed evenly. Soil analysis was conducted through the drying stage at temperature of $105^{\circ} \mathrm{C}$. Soil texture was analyzed by separating sand, silt and clay particles through quantitative method of mechanical analysis process. Soil acidity $(\mathrm{pH})$ was measured in soil and water mixture extracts (1: 5); C organic content by Walkley-Black method; $\mathrm{N}$ total by Kjeldahl method; P analysis by Bray I method; K, Fe, and Mn analysis by Morgan method. Exchangeable base cations $\left(\mathrm{K}^{+}, \mathrm{Na}^{+}, \mathrm{Ca}^{2+}\right.$ and $\mathrm{Mg}^{2+}$ ) were determined by extraction method with ammonium acetate whilst acidic cations $\left(\mathrm{Al}^{3+}, \mathrm{H}^{+}\right)$with sodium chloride. 


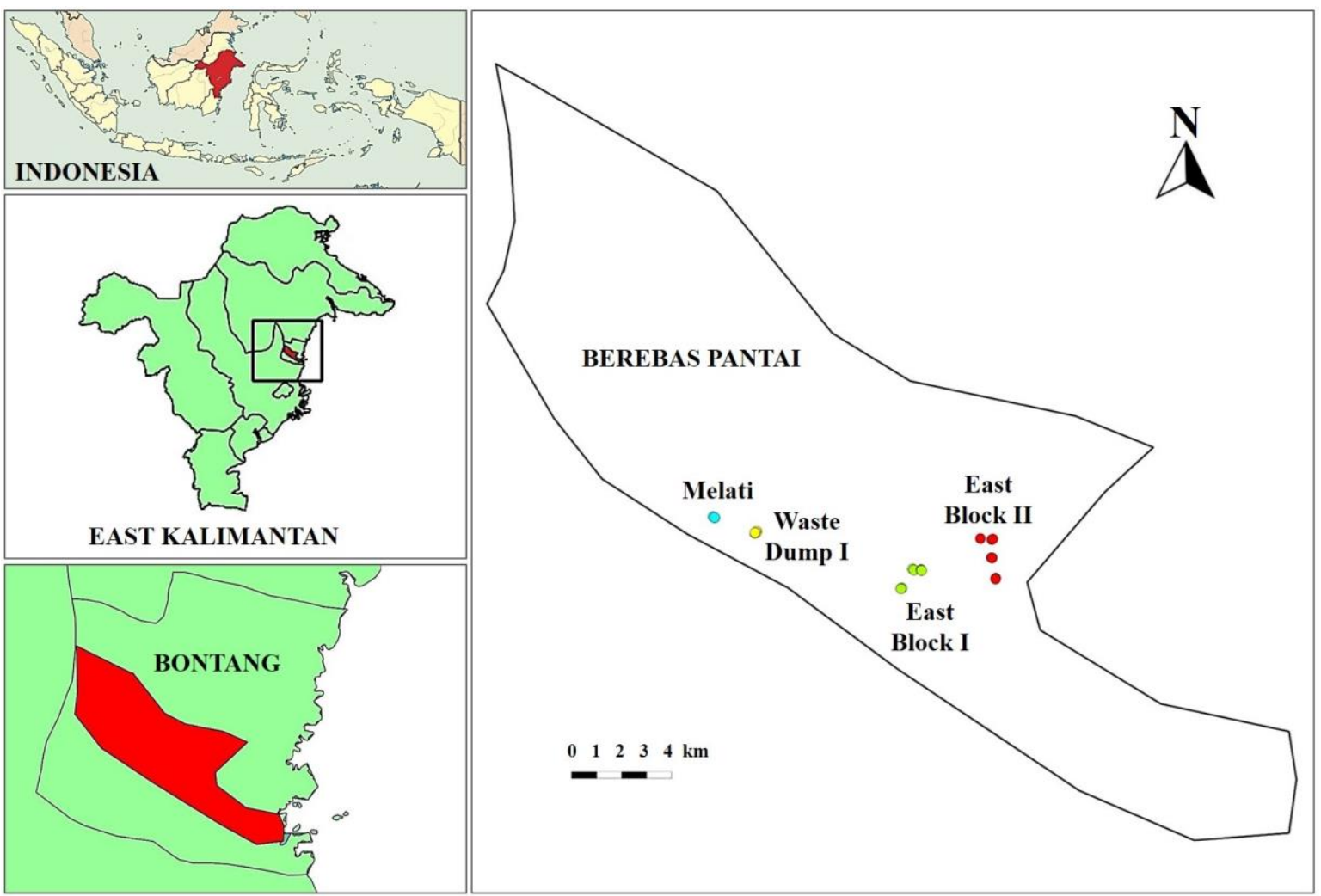

Figure 1. Location of the study area in Berebas Pantai, Bontang, East Kalimantan: Reclamation sites i.e. Melati and Waste Dump I; and Pre-mining sites i.e. East Block I; and East Block II

\section{Invasive alien species and noxious weed species}

assessment

The determination of invasive alien status and noxious weed of a plant species was assessed using the world invasive species online databases includes (i) Southeast Asian Regional Centre for Tropical Biology (SEAMEO BIOTROP) database on invasive alien species, which is available at http://kmtb.biotrop.org/collections/spias; (ii) Global Invasive Species Database (GISD) by the Invasive Species Specialist Group (ISSG) of the Species Survival Commission (SSC) of the International Union for Conservation of Nature (IUCN), which is available at http://www.iucngisd.org/gisd/; (iii) Invasive Species Compendium (ISC), which is available at https://www.cabi.org/isc; and (iv) United States Department of Agriculture Natural Resources Conservation Service (USDA-NRCS), which is available at https://plants.usda.gov/java/noxious. Further, IAS designations were also cross-checked using other published references i.e. books and journal articles.

\section{Data analysis}

The vegetation analysis data in all sampling plots were tabulated and calculated. Spontaneous plant recolonization composition was evaluated by analyzing the frequency, density, abundance, species important value index (IVI) and Shannon-Wiener diversity index according to Ludwig and Reynolds (1988). Multivariate clustering analysis was also conducted to identify the compositional variation pattern of spontaneous plant species found in reclamation sites (data from this study) compared to pre-mining sites data referred to Budiharta et al. (2020, data not shown). Clustering analysis was employed by statistical software Paleontological Statistics (PAST) version 1.94b using Jaccard similarity index (Hammer et al. 2001).

\section{RESULTS AND DISCUSSION}

\section{Reclamation sites characteristics}

The previous forests on both reclamation sites studied here were considered as secondary tropical lowland forests (Budiharta et al. 2020, data not shown), with altitudes less than $200 \mathrm{~m}$ above sea level (Table 1). Further, Waste Dump I site was reclaimed in 2001 by pioneer plants, mostly from Leguminosae i.e. Senna siamea, Albizia falcataria, and small portion of Acacia mangium, also Gmelina arborea (Lamiaceae). Whilst, Melati site was reclaimed in 2009 with pioneer plants mostly Senna siamea, Albizia saman and Albizia falcataria (Leguminosae), also small portion of Swietenia mahagoni (Meliaceae). The landscape area of the 9-y.o. site was considered more open and had higher air temperature and light intensity compared to the 17-y.o. site. Likewise, air moisture (relative humidity) in both sites during fieldwork (rainy season) was quite high, which in the 17-y.o. site was more humid than the 9-y.o. site (Table 1). It may due to the larger canopy coverage in the older site which affected to 
the micro-climates of the site.

Selection and management of pioneer plants for reclamation of degraded land is very important, and become one of the keys to reclamation success. Leguminosae as pioneer plants may grow quickly and adaptable to poor soil conditions with lack of nutrients, effectively increase infiltration of topsoil, reduce run-off and cope with landslides. It is also able to improve soils and micro-climates, the degraded leaves act as green manure, the canopy provides full shade for understories and help to keep air moisture around the plants. Further, roots of legumes may form a symbiotic relationship of nitrogen binding with many strains of Rhizobium and other $\mathrm{N}$-fixing microbes, which provide nitrogen mineral in soils for other plants surrounds (Dashora 2011; Sein and Mitlöhner 2011). The pioneer species also should initially have high population growth rate, and then declining growth rates when they are replaced by late-successional species (Silvestrini and Dos Santos 2015). This study showed that Leguminosae plants as pioneers have low to moderate longevity so that in time they will die, then later be replaced by native tree species. A decrease in the number of large pioneer trees was already found in both sites, however the number even higher at the older site than the younger site.

\section{Spontaneous plant diversity, composition, and structure}

Vegetation analysis showed that spontaneous plants have been recolonized on both reclamation sites in two layers i.e. understory and sapling; whilst pole and tree layers were not yet available. Further, spontaneous plant diversity indices on both reclamation sites were categorized as moderate at both layers $\left(\mathrm{H}^{\prime}<3\right)$, where the 9-y.o. reclamation site had slightly higher values than the 17-y.o (Table 2). Nonetheless, those diversity indices were considered lower than the nearby secondary forest of premining sites. The diversity indices of understories and saplings in pre-mining sites were categorized as high, reached to 3.50-3.71 and 3.35-3.31 respectively (Budiharta et al. 2020, data not shown).

Yet, the number of plant species found at each layer in the older reclamation site was slightly larger than the younger site. It may due to some of plant species in the older reclamation site found in large populations, which indicated by its higher plant density up to 125,962 individual understory per hectare and 3,692 individual sapling per hectare (Table 2). Previous study by Mukhtar and Heriyanto (2012) on spontaneous tree saplings and seedlings at 6,10 and 12 years old reclamation sites of post-coal mining in East Kutai (East Kalimantan) reported smaller number of spontaneous species grown on reclamation sites. Three species of seedlings were recorded 6 y.o. and 10 y.o. sites with density 2,000 and 3,500 individual/ha, respectively; and 7 species of seedlings were recorded at 12 y.o. site with density 7,500 individual/ha. Further, no sapling available at 6 y.o. site; two species of saplings were recorded at 10 y.o. site with density 1,000 individual/ha; and 5 species of saplings were recorded at 12 y.o. site with density 3,000 individual/ha. Hence, two reclamation sites in this study experienced moderately establishment of spontaneous plant and succession progress.

\section{Understory layer}

Diverse spontaneous plants at understory layer have been inventoried on both reclamation sites. About 38 spontaneous plant species belonging to 35 genera and 29 families were recorded at understory layer in the 9-y.o. site, with Euphorbiaceae, was the highest species number found (6 species), followed by Poaceae (4), and Leguminosae (2 species), etc. Whilst, in the 17-y.o. site has slightly higher number and more diversity of plant species (40 species), belonging to 40 genera and 28 families, with Euphorbiaceae and Poaceae were the highest species number (4 species each), followed by Asteraceae (3 species), Rubiaceae (2 species), and Leguminosae (2 species), etc.

Table 1. Comparison of actual environmental conditions during the fieldworks on two reclamation sites

\begin{tabular}{lll}
\hline Parameter & $\begin{array}{c}\text { Melati } \\
\text { (9-y.o. reclamation) }\end{array}$ & $\begin{array}{c}\text { Waste Dump I } \\
(\mathbf{1 7 - y . 0 . ~ r e c l a m a t i o n )})\end{array}$ \\
\hline Altitude (m asl.) & $124.75 \pm 3.77$ & $163.00 \pm 2.45$ \\
Air relative humidiy $(\%)$ & $84.50 \pm 0.50$ & $86.50 \pm 1.00$ \\
Air temperature $\left({ }^{\circ} \mathrm{C}\right)$ & $26.48 \pm 0.86$ & $26.10 \pm 1.17$ \\
Light intensity (lux) & $4,087.50 \pm 3,318.07$ & $3,126.25 \pm 1,896.45$ \\
\hline
\end{tabular}

Table 2. Comparison of spontaneous plant diversity indices on two reclamation sites

\begin{tabular}{llll}
\hline Vegetation layer & Diversity indices & $\begin{array}{c}\text { Melati } \\
\text { (9-y.o. reclamation) }\end{array}$ & $\begin{array}{c}\text { Waste Dump I } \\
\text { (17-y.o. reclamation) }\end{array}$ \\
\hline Understory & Shannon-Wiener diversity index/ H' & 2.62 & 2.46 \\
& Number of species & 38 & 40 \\
\multirow{3}{*}{ Sapling } & Density (individual/ha) & 124,423 & 125,962 \\
& Shannon-Wiener diversity index/ H' & 2.68 & 2.56 \\
& Number of species & 20 & 23 \\
& Density (individual/ha) & 2,492 & 3,692 \\
\hline
\end{tabular}



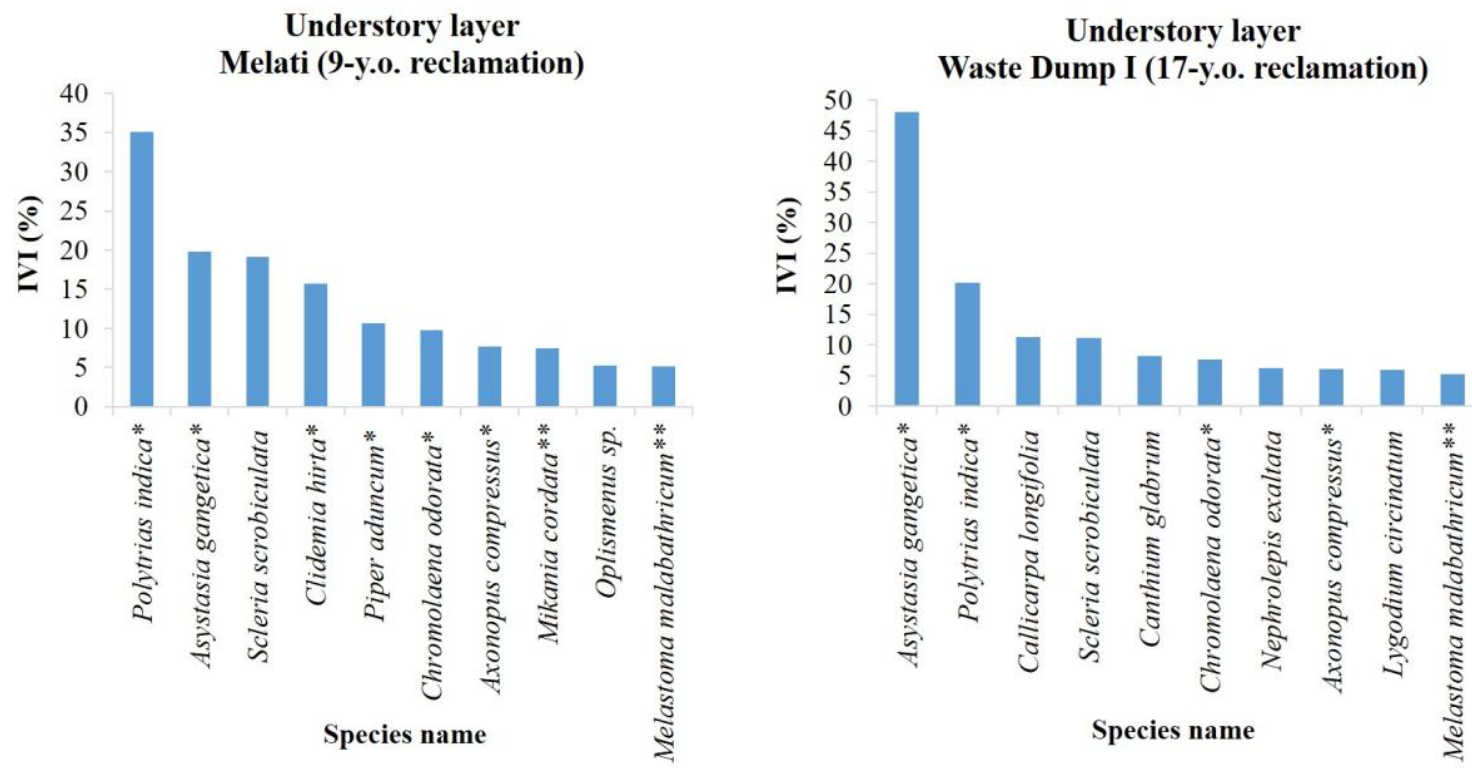

Figure 2. Ten spontaneous plant species with high important value index (IVI) at understory layer on two reclamation sites. Notes: *= invasive alien species, $* *=$ noxious weed species

According to plant habit categorization, understory layer on both sites was composed mostly by shrubs to small trees, then followed by tree seedlings, grasses, ferns, herbaceous, and lianas. Some shrub species recorded include species from families Asteraceae, Acanthaceae, Melastomaceae, Solanaceae, Malvaceae, etc. Whilst, small trees recorded such as species from families Rubiaceae, Rutaceae, Lamiaceae, etc. Further, seedlings of tree species in the 17-y.o. site was considered higher than the 9-y.o. reclamation site. Diverse tree species seedlings from the family Euphorbiaceae, and Leguminosae which are known as general spontaneous pioneer plants on disturbed sites well grown on both sites such as Macaranga spp., Mallotus spp., Glochidion spp., Senna siamea, Acacia mangium, etc. Those $S$. siamea and A. mangium were considered as spontaneous tree seedlings from the pioneer trees planted for initial reclamation. Other several spontaneous tree species also have been found in small populations in the 17-y.o. site, namely Ficus septica, Uvaria sp., Cratoxylum sumatranum, and Guioia pleuropteris.

Meanwhile, based on species dominancy and important values, the 9-y.o. site was mostly dominated by grass species i.e. Polytrias indica, whereas the 17-y.o. site was mostly dominated by shrub species of Asystasia gangetica (Figure 2, Figure 4). Spontaneous plant species competition on each site was indicated in this study. In general, grasses are less dominant in the older site, due to the lower light intensity penetration by large pioneer trees canopy shades compared to the younger site. Shrub species such as Clidemia hirta and Chromolaena odorata were dominant on both sites, however their species important values were considered higher in the younger site. Different from the younger site, some seedlings of small trees include Callicarpa longifolia, Canthium glabrum and terrestrial ferns such as Nephrolepis exaltata and Lygodium circinatum were dominated the older site.

Interestingly, several dominant spontaneous understory plants on both reclamation sites were categorized as IAS (Figure 2, Figure 4). Seven dominant species were considered IAS in the 9-y.o. reclamation site includes Polytrias indica, Asystasia gangetica, Clidemia hirta, Piper aduncum, Chromolaena odorata, and Axonopus compressus; whereas in the 17-y.o. reclamation site was only four species, specifically Asystasia gangetica, Clidemia hirta, Chromolaena odorata, and Axonopus compressus. In addition, M. malabathricum was considered dominant species on both sides, although not included as IAS, this species is potential to be invasive (Hapsari et al. 2014). M. cordata was also dominant species on the younger site, it exists as a native species of IAS Mikania micrantha (Su et al. 2018); however, it was reported as serious threat like IAS in reclamation site in Kintap, Tanah Laut, South Kalimantan (Yusuf and Arisoesilaningsih 2017). Further, both M. malabathricum and M. cordata were included as noxious weeds, which determined to be injurious to public health, crops, livestock, agricultural lands and other properties (USDA-NRCS 2019). Each IAS and noxious weed species has invasiveness traits that make them well-grown, successfully recolonized and invaded the disturbed area.

In addition, herbaceous species found in the 9-y.o. site was composed by only Zingiberaceae i.e. Etlingera sp. and Plagiostachys sp. whereas in the 17-y.o. sites was more diverse, includes Curculigo orchioides (Hypoxidaceae), Alocasia princeps (Araceae), and Alpinia sp. (Zingiberaceae). Herbaceous plants preferable at moist habitats with high air relative humidity and low light intensity or shade tolerant, therefore well grown at the 17y.o. site compared to the 9 -y.o. site. Terrestrial fern species 
in the 9-y.o. site was exhibited high diversity, includes Asplenium nidus, Christella dentata, Davallia denticulata, Lygodium circinatum, Lygodium sp. and Nephrolepis exaltata. Whilst, 17-y.o. site was lower in species number, but the population of each species was considered higher than the 9-y.o. site. It may due to the soil properties and micro-climatic conditions differences on both sites. Ferns are also considered as potential ecological indicators of environmental quality because they are directly affected by disturbances (Bergeron and Pellerin 2014; Silva et al. 2018). In addition, some lianas both woody and non-woody found on both sites include Smilax gigantea, Tetracera scandens, Gymnema sp., Passiflora foetida, and Mikania micrantha (Figure 4).

\section{Sapling layer}

At sapling layer, about 23 spontaneous plant species (14 genera) was inventoried in the 17-y.o. site whereas at 9-y.o site was 20 species (12 genera). Their plant habitus composed of tree and small tree saplings. Plant species from Euphorbiaceae and Phyllantaceae families were the highest species number found in both reclamation sites. Phyllantaceae family is very closely related to Euphorbiaceae, and is considered as a segregate of Euphorbiaceae sensu lato (APG IV 2016). In addition, another sapling species from Lamiaceae, Sapindaceae, and Leguminosae families also found in high species numbers at the younger site, whereas at the older site were Melastomaceae and Rutaceae.

Based on the species dominancy and important values, the 17-y.o. site was higher dominated by Euphorbiaceae and Phyllantaceae than the 9-y.o. site, i.e. 5 species and 3 species, respectively (Figure 3, Figure 5). Macaranga tanarius was the dominant species at the older site with highest IVI whereas in the 9-y.o. site was dominated by Glochidion obscurum. Both M. tanarius and G. obscurum were considered as fast-growing pioneers of open and disturbed sites (Slik et al. 2003; Chia et al. 2017; Karyati et al. 2018). Meanwhile, another Euphorbiaceae species i.e. Macaranga triloba and Homalanthus populneus were found dominated the 6 y.o. and 10 y.o. reclamation sites in KPC Sangata, East Kutai, East Kalimantan (Mukhtar and Heriyanto 2012).

The abundance of Euphorbiaceae and Phyllantaceae, particularly Macaranga and Mallotus species was closely related to the level of disturbances. Most of Macaranga species were indicated of high disturbance levels, while most Mallotus species preferred intermediate to low levels of disturbance (Slik et al. 2003). Further, both Macaranga and Mallotus species have allelopathic potentials so that readily established and dominated the reclamation sites (Sher et al. 2014; Camino 2014). Two species of Macaranga and one species of Mallotus were found dominant at the older site whereas at the younger site was only found one species of Mallotus which considered dominant.

In addition, sapling of $M$. malabathricum as noxious weed was found dominant on both sites, with species important value in the 9-y.o. site was higher than the 17y.o. site (Figure 3, Figure 5). Likewise, this noxious weed was also dominant at 12 y.o. reclamation sites in KPC Sangata, East Kutai, East Kalimantan (Mukhtar and Heriyanto 2012). Further, only one IAS was identified as dominant in the 9-y.o. site, i.e. Piper aduncum. Whilst, in the 17-y.o. P. aduncum was recorded but not dominant. This species is considered as small tree pioneer with high competitiveness in secondary forest (Padmanaba and Sheil 2014).
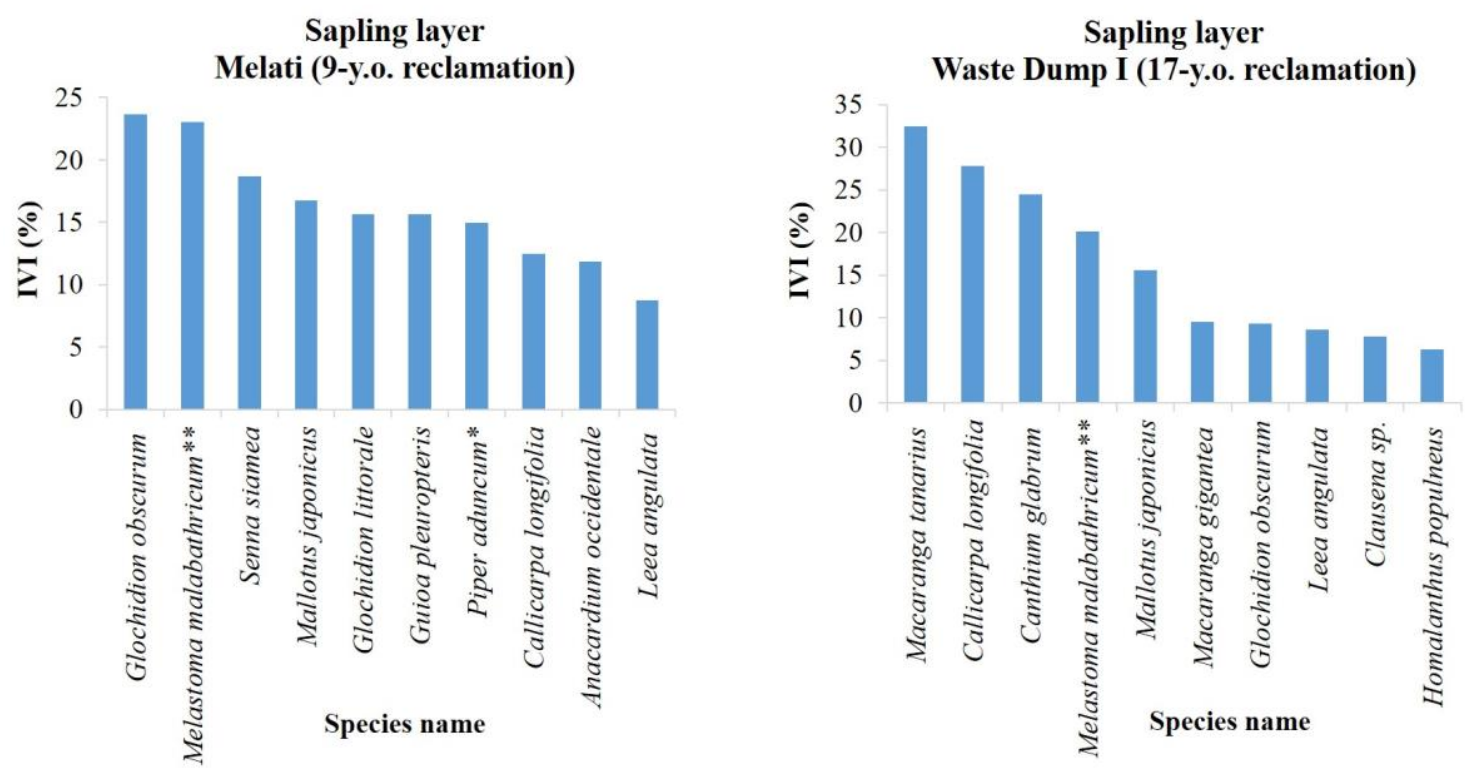

Figure 3. Ten spontaneous plant species with high important value index (IVI) at sapling layer on two reclamation sites. Notes: *= invasive alien species, $* *=$ noxious weed species 


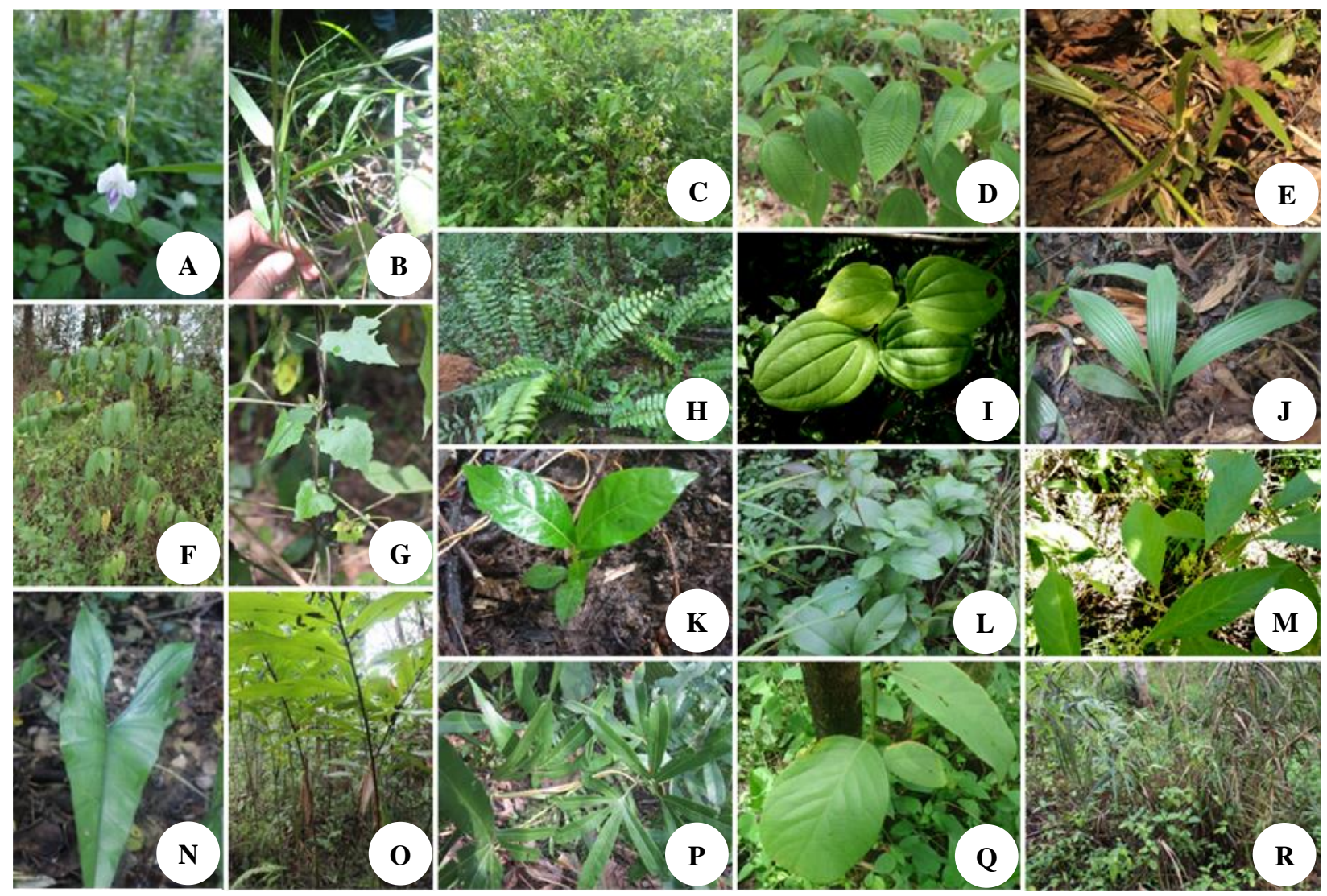

Figure 4. Some understory spontaneous plants found on reclamation sites: A. Asystasia gangetica*, B. Polytrias indica*, C. Chromolaena odorata*, D. Clidemia hirta*, E. Axonopus compressus*, F. Piper aduncum*, G. Mikania cordata**, H. Chrystella dentata, I. Smilax gigantea, J. Curculigo orchioides, K. Ficus septica, L. Tetracera scandens, M. Callicarpa longifolia, N. Alocasia princeps, O. Etllingera sp., P. Lygodium circinnatum, Q. Bridelia stipularis, and R. Scleria scrobiculata. Notes: *= invasive alien species; $* *=$ noxious weed species
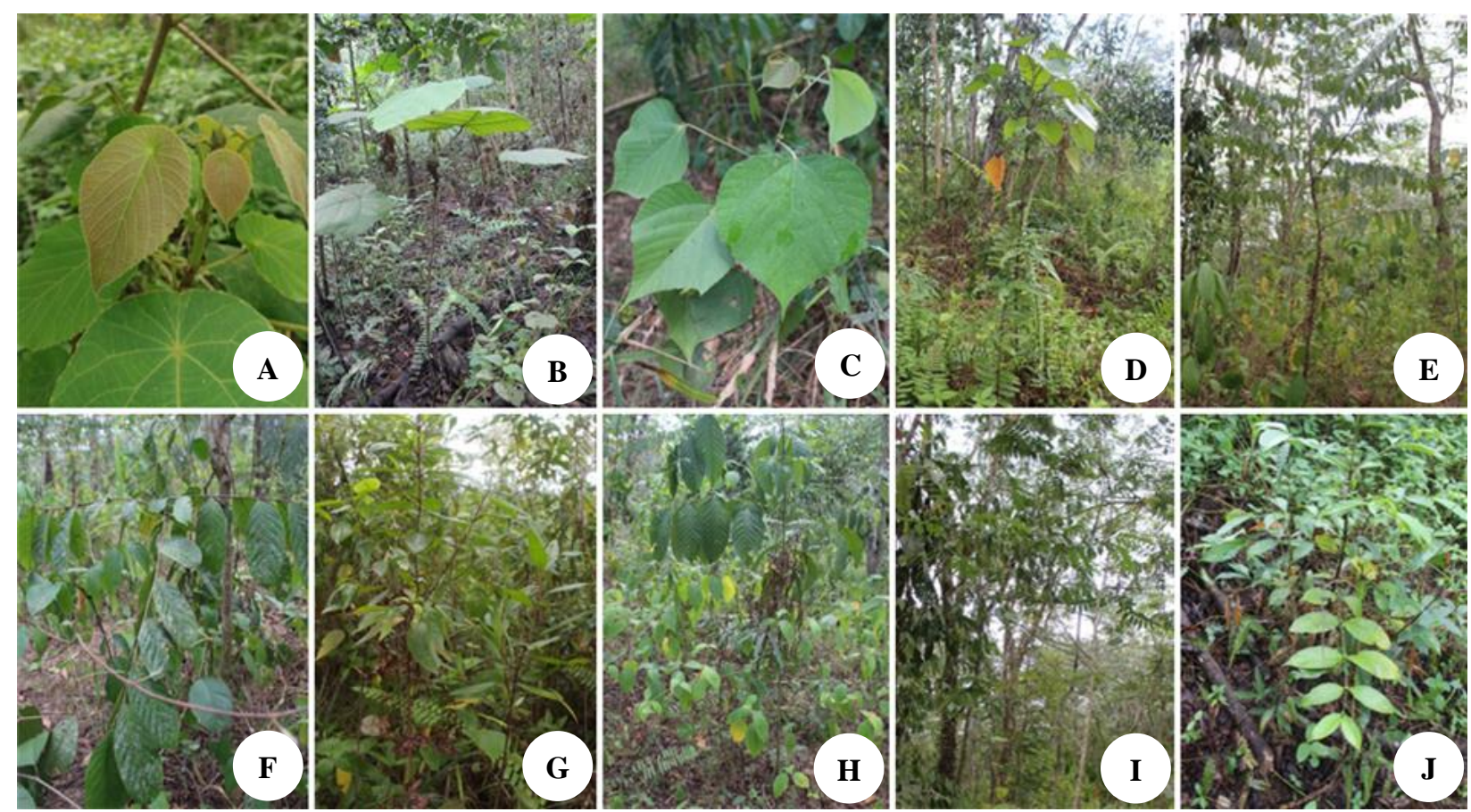

Figure 5. Some dominant species at sapling layer: A. Macaranga tanarius, B. Macaranga gigantea, C. Mallotus japonicus, D. Homalanthus populneus, E. Glochidion obscurum, F. Glochidion littorale, G. Melastoma malabathricum**, H. Leea angulata, I. Senna siamea, and J. Cathium glabrum. Note: $* *=$ noxious weed species 


\section{Invasion of spontaneous alien species on reclamation sites}

This study has identified seven IAS in the 9-y.o. site, which six out of seven species were dominant. Meanwhile, in the 17-y.o. site was recorded eight IAS but only four species were dominant (Table 2). The IAS recorded on reclamation sites comprised Asystasia gangetica, Axonopus compressus, Chromolaena odorata, Clidemia hirta, Imperata cylindrica, Mimosa pudica, Passiflora foetida, Piper aduncum, and Polytrias indica. The invasion of IAS mostly in understory layer with plant habitus of shrubs, grasses, and lianas. $P$. aduncum was the only IAS found at sapling layer. It has been identified on both sites, however, it was considered dominant only in the 9-y.o. site. In addition, three species were included as noxious weeds i.e. I. cylindrica, M. malabathricum, and $M$. cordata. According to this finding, the younger site has experienced larger invasion of IAS than the older site.

Some reclamation sites in Kalimantan were also reported to have threats from IAS, such as in Kintap site (Tanah Laut, South Kalimantan) threatened by M. pudica, Ageratum conyzoides, and $C$. odorata (Yusuf and Arisoesilaningsih 2017). Whilst, IAS in Adaro site (South Kalimantan) consisted A. conyzoides, C. odorata, $M$. micrantha, V. cinerea, M. pigra, M. pudica, P. foetida, I, cyllindrica, and Paspalum conjugatum (Soendjoto et al. 2014). IAS recorded in KPC Sangata (East Kutai, East Kalimantan) includes A. conyzoides, Lantana camara, and M. pudica (Mukhtar and Heriyanto 2012); whereas in Muara Begai (East Kutai, East Kalimantan) consisted $A$. gangetica, C. odorata, I. cylindrica, and P. conjugatum (Lestari et al. 2019).

The invasiveness (traits that enable a species to invade a new habitat) and invasibility (susceptibility of a community or habitat to the establishment and spread of new species) are key components for the occurrence and spread of alien plants (Richardson and Rejmanek 2011; Lemke et al. 2012). In addition to its biological characteristics and what ecological role the species may play, another factor such as its tolerance to environments in the new range also influenced the invasion. The key invasiveness traits of each IAS and noxious weed species found on both reclamation sites from this study are presented in Table 3.

Large ecological niche breadth is believed to contribute to invasive success (Valladares et al. 2016). Some of the favor traits for early succession in reclamation, including fast establishment, the ability to grow under harsh conditions and adaptation to nutrient-poor soils also heavy metal-polluted soils, etc. are highly related to invasive tendencies. Some studies reported that the abundance of understory IAS was associated with environmental variables on disturbed site include open habitat, higher light intensity, and air temperature, lower elevation, burnt sites, close to the forest edges with direct anthropogenic influence, etc. (Robiansyah and Purnomo 2013). Postmining sites often display those habitat attributes and thus may have a high probability of being invaded by IAS. Further, the characteristics of plants that assist in some of the short-term goals of restoration, including land stabilization, soil erosion prevention, nitrogen-fixing, etc. are often the same traits that are associated with invasive plants (Lemke et al. 2012; Kabrna et al. 2013; Tischew et al. 2013).

Most of the IAS and noxious weed species identified in this study have wide environmental tolerance, vigorous performance, and high competitiveness, fast-growing with short juvenile periods, developed vegetative propagules and wide disperse of small seed mass, high seed viability and long term seed viability, etc. (Table 3); therefore they rapidly invade and recolonize newly disturbed areas. Grasses such as $I$. cylindrica, $A$. compressus, and $P$. indica have extensive rhizome system, and some have underground tubers. They are highly adapted to poor soils, pollution, and drought, and have genetic plasticity and fire tolerance (Table 3). Nonetheless, A. compressus can minimize soil erosion in undulating and hilly areas (ISC 2019). Likewise, M. pudica has been identified for having potential phytoremediation of arsenic polluted areas (GISD 2019), while $P$. foetida can grow at the sulfate acid soil (SEAMEO BIOTROP 2019), and M. malabathricum considered as acidic tolerant and heavy metal hyperaccumulator (Patek-Mohd et al. 2018). Some shrubs and liana species such as A. gangetica, C. hirta, C. odorata, $M$. cordata, $M$. pudica, and $P$. foetida grow dense thickets which can smother and outcompete any vegetation with its herbaceous layer, and preventing any spontaneous forest regeneration. Further, I. cylindrica, $C$. odorata, $M$. malabathricum, and $M$. cordata have allelopathic effects that prevent the establishment of other plant species $(\mathrm{Hu}$ and Zhang 2013; Hossain et al. 2016; Hagan et al. 2013). However, in general, their herbaceous layers may provide mulches, moistures for soils, and improve micro-climates. $P$. aduncum was the only tree species of IAS recorded in reclamation area studied. It is fast-growing and forms dense thickets which highly outcompete the native species and decrease biodiversity, also high seed viability (Padmanaba and Sheil 2014).

Plant invasion particularly IAS poses a serious threat, since it has tendency to disrupt diverse native species either by direct displacement or through its indirect effects on the ecosystem (Richardson and Rejmanek 2011). Although, in some points, they may have roles in the initial reclamation and plant succession on disturbed sites. Managing those existing and future IAS at reclaimed coal-mined sites particularly the dominant species is recommended to mitigate the risk of negative impacts of the IAS invasion, particularly to the direction of successional changes. Need to be concerned in particular; $C$. hirta, and C. odorata were included as 100 of the world's worst invaders worldwide (Lowe et al. 2000); also I. cylindrica, M. malabathricum and $M$. cordata as noxious weeds. 
Table 3. Occurrence and key invasiveness traits of spontaneous IAS and noxious weed species recolonization on two reclamation sites

\begin{tabular}{|c|c|c|c|c|c|c|c|}
\hline \multirow{2}{*}{ Species name } & \multirow{2}{*}{ Local name } & \multirow{2}{*}{ Family } & \multirow{2}{*}{ Habitus } & \multirow{2}{*}{ Origin } & \multicolumn{2}{|c|}{ Occurrence } & \multirow[b]{2}{*}{ Key invasiveness traits } \\
\hline & & & & & Melati & WD I & \\
\hline $\begin{array}{l}\text { Asystasia } \\
\text { gangetica }{ }^{1,2,3}\end{array}$ & $\begin{array}{l}\text { Ara sungsang } \\
\text { (Indon.), Chinese } \\
\text { violet (Eng.) }\end{array}$ & Acanth. & Shrub & Africa & $\begin{array}{l}\sqrt{ } \\
\text { (D) }\end{array}$ & $\begin{array}{l}\sqrt{ } \\
\text { (D) }\end{array}$ & $\begin{array}{l}\text { Wide environmental tolerance at open space to shaded; grows vigorously and form } \\
\text { dense mats which can smother any vegetation with its herbaceous layer; propagate } \\
\text { both vegetative and generative; high seeds production and } 85 \% \text { viability; long term } \\
\text { seed viability up to } 8 \text { months in soil, easy to germinate; short juvenile period. }\end{array}$ \\
\hline $\begin{array}{l}\text { Axonopus } \\
\text { compressus } 1,3\end{array}$ & $\begin{array}{l}\text { Rumput paitan } \\
\text { (Indon.), Carpet } \\
\text { grass (Eng.) }\end{array}$ & Poac. & Grass & $\begin{array}{l}\text { Tropical } \\
\text { America }\end{array}$ & $\begin{array}{l}\sqrt{ } \\
\text { (D) }\end{array}$ & $\begin{array}{l}\sqrt{ } \\
\text { (D) }\end{array}$ & $\begin{array}{l}\text { Wide environmental tolerance at open space to shaded, from moist to dry areas; } \\
\text { stoloniferous perennial grass spreads by above-ground runners and seeds; stolons } \\
\text { persistent during long dry season and can withstand of tramplings. }\end{array}$ \\
\hline $\begin{array}{l}\text { Chromolaena } \\
\text { odorata }^{1,2,3}\end{array}$ & $\begin{array}{l}\text { Kirinyuh (Indon.), } \\
\text { Siam weed (Eng.) }\end{array}$ & Aster. & Shrub & $\begin{array}{l}\text { Central \& } \\
\text { South America }\end{array}$ & $\begin{array}{l}\sqrt{ } \\
\text { (D) }\end{array}$ & $\begin{array}{l}\sqrt{ } \\
\text { (D) }\end{array}$ & $\begin{array}{l}\text { Wide environmental tolerance; fast-growing; propagate both vegetative and } \\
\text { generative; forms dense tangled bushes; preventing establishment of other species } \\
\text { both due to competition and allelopathic effects; has small seeds with long term } \\
\text { seed viability and long-distance dispersed by wind. }\end{array}$ \\
\hline Clidemia hirta ${ }^{1,2,3}$ & $\begin{array}{l}\text { Harendong bulu } \\
\text { (Sunda, Indon.), } \\
\text { Koster's curse (Eng.) }\end{array}$ & Melast. & Shrub & South America & $\begin{array}{l}\sqrt{ } \\
\text { (D) }\end{array}$ & $\begin{array}{c}\sqrt{ } \\
(\mathrm{ND})\end{array}$ & $\begin{array}{l}\text { Wide environmental tolerance at open space or slightly shaded also thrives in dry } \\
\text { area; forms dense thicket; flowering and fruiting throughout the year with prolific } \\
\text { production of seeds, seeds may remain dormant for up to four years in the soil. }\end{array}$ \\
\hline $\begin{array}{l}\text { Imperata } \\
\text { cylindrica } 2,3,4\end{array}$ & $\begin{array}{l}\text { Alang-alang } \\
\text { (Indon.), Cogon } \\
\text { grass (Eng.) }\end{array}$ & Poac. & Grass & Eastern Africa & Absent & $\begin{array}{c}\sqrt{ } \\
(\mathrm{ND})\end{array}$ & $\begin{array}{l}\text { Very plastic habitat, adapted to poor soils, drought and fire; has extensive rhizome } \\
\text { system; tolerant in high light intensity, high temperatures and limited soil moisture, } \\
\text { has allelopathic effect. }\end{array}$ \\
\hline $\begin{array}{l}\text { Melastoma } \\
\text { malabathricum }{ }^{4}\end{array}$ & $\begin{array}{l}\text { Harendong (Indon.), } \\
\text { Malabar melastome } \\
\text { (Eng.) }\end{array}$ & Melast. & Shrub & $\begin{array}{l}\text { Tropical Asia } \\
\text { and the Pacifics }\end{array}$ & $\begin{array}{l}\sqrt{ } \\
\text { (D) }\end{array}$ & $\begin{array}{l}\sqrt{ } \\
\text { (D) }\end{array}$ & $\begin{array}{l}\text { Wide environmental tolerance, adapted to poor and acidic soils, heavy metal hyper- } \\
\text { accumulator, propagate both vegetative and generative; high seed dispersal } \\
\text { capacity; fast-growing; form dense bushes with high competitiveness and has } \\
\text { allelopathic effect. }\end{array}$ \\
\hline${ }_{3}^{\text {Mimosa pudica }}{ }^{1,2}$ & $\begin{array}{l}\text { Putri malu (Indon.), } \\
\text { Sensitive plant } \\
\text { (Eng.) }\end{array}$ & Mimos. & Shrub & $\begin{array}{l}\text { Tropical } \\
\text { America/ South } \\
\text { America }\end{array}$ & $\begin{array}{c}\sqrt{ } \\
(\mathrm{ND})\end{array}$ & Absent & $\begin{array}{l}\text { It may grow as a single plant or in tangled thickets; shade tolerant; adapted to poor } \\
\text { soils, and outcompeted on rich soils; requires disturbed soils to establish itself, } \\
\text { repeated burning may encourage its spread in pastures; flowering throughout the } \\
\text { year, seeds germinate within } 2 \text { weeks. }\end{array}$ \\
\hline Mikania cordata ${ }^{4}$ & $\begin{array}{l}\text { Brodjo lego (Java), } \\
\text { Mile-a-minute } \\
\text { (Eng.) }\end{array}$ & Aster. & Liana & $\begin{array}{l}\text { Tropical Asia } \\
\text { and the Pacifics }\end{array}$ & $\begin{array}{l}\sqrt{ } \\
\text { (D) }\end{array}$ & Absent & $\begin{array}{l}\text { Fast-growing; forms dense thickets by the numerous intermingled stems and stolons } \\
\text { which smothering shrubs and small trees; has allelopathic effect; spreads rapidly } \\
\text { after disturbances; wide expand by vegetative propagules and seeds; flowering and } \\
\text { fruiting throughout the year; small seeds dispersed by wind. }\end{array}$ \\
\hline $\begin{array}{l}\text { Passiflora foetida } \\
2,3\end{array}$ & $\begin{array}{l}\text { Rambusa (Indon.), } \\
\text { Stinking passion } \\
\text { flower (Eng.) }\end{array}$ & Passif. & Liana & $\begin{array}{l}\text { Tropical } \\
\text { America }\end{array}$ & Absent & $\begin{array}{c}\sqrt{ } \\
(\mathrm{ND})\end{array}$ & $\begin{array}{l}\text { Favors wet areas but can tolerate dry conditions; forms dense ground cover which } \\
\text { prevents the other species establishment; long term seed viability, wide dispersed } \\
\text { by mammals and birds. }\end{array}$ \\
\hline Piper aduncum ${ }^{1,2,3}$ & $\begin{array}{l}\text { Sirih hutan (Indon.), } \\
\text { Spiked pepper (Eng.) }\end{array}$ & Piper. & $\begin{array}{l}\text { Small } \\
\text { Tree }\end{array}$ & South America & $\begin{array}{l}\sqrt{ } \\
\text { (D) }\end{array}$ & $\begin{array}{c}\sqrt{ } \\
(\mathrm{ND})\end{array}$ & $\begin{array}{l}\text { High competitive in forest, forests gaps, and disturbed sites; shade-tolerant; fast- } \\
\text { growing and forms dense thickets; produce fruits continuously with large number } \\
\text { of seeds, seeds long dispersed by birds bats and wind; may be introduced to new } \\
\text { locations as a contaminant of logging equipment. }\end{array}$ \\
\hline Polytrias indica ${ }^{1}$ & $\begin{array}{l}\text { Rumput Embun } \\
\text { (Indon.), Indian } \\
\text { murainagrass (Eng.) }\end{array}$ & Poac. & Grass & India & $\begin{array}{l}\sqrt{ } \\
\text { (D) }\end{array}$ & $\begin{array}{l}\sqrt{ } \\
\text { (D) }\end{array}$ & $\begin{array}{l}\text { Wide environmental tolerance from sunny to lightly shaded; adapted to poor soils, } \\
\text { dry, on light or heavy texture; rapidly propagated by stolon and seeds. }\end{array}$ \\
\hline
\end{tabular}

Note: Reference: 1. SEAMEO BIOTROP, 2. GISD, 3. ISC, 4. USDA-NRCS. Notes: $(\mathrm{D})=$ species dominant, $(\mathrm{ND})=$ species not dominant 


\section{Clustering pattern of spontaneous plant species composition}

Clustering analysis subjected to the species compositional variation of understory and sapling layers on reclamation sites compared to the surrounding secondary forest of pre-mining sites showed that both reclamation sites had only $20 \%$ species similarity with the pre-mining sites, which means still along way to go to the previous natural picture of species composition (Figure 6). In total, about 50 spontaneous plant species recorded in Melati site and 54 species in Waste Dump I site, with relatively high similarity about $38 \%$. The complete spontaneous plant species list on both reclamation sites was available at Table S1. Meanwhile, two landscapes of pre-mining sites showed about $33 \%$ similarity with higher species number recorded, i.e. 85 species recorded in East Block I and 99 species in East Block II. Understory and sapling layers of both premining sites were dominated by more diverse species, and some native species with high conservation value also recorded although not dominant such as Irvingia malayana, Eusideroxylon zwageri, Ficus spp., etc. (Budiharta et al. 2020, data not shown.).

Further in details, about 27 same plant species were found on both reclamation sites, and 14 same species occurred on four sites includes Mallotus japonicus, Homalanthus populneus, Melastoma malabathricum, Callicarpa longifolia, Canthium glabrum, Cratoxylum sumatranum, Pternandra galeata; Leea angulata, Lygodium circinatum, Nephrolepis exaltata, Oplismenus $c f$. burmanii, Polytrias indica, Mikania cordata and Tetracera scandens. Those species were considered as general understories and saplings species component of secondary tropical forest; comprises of some trees of Euphorbiaceae species; small trees and shrubs of Melastomaceae, Lamiaceae, Rubiaceae, Leeaceae, etc.; ferns, grasses, and lianas.

More diverse spontaneous plant species were reported by Komara et al. (2016) on 16 y.o. reclamation site of postcoal mining in East Kutai, East Kalimantan. It comprised of some pioneers such as Leucaena glauca, Homalanthus populneus, Bauhinia sp, etc.; some important Kalimantan tree species for timber such as Shorea laevis, Koompassia malaccensis, and Actinodaphne glomerata; also some edible fruit tree species such as Lansium domesticum, Durio zibethinus, Averrhoa carambola, Artocarpus champeden, etc. Those diverse plant species presumably due to the activity of animals found near the reclamation site which act as dispersal agents from the surrounding natural forest as the seeds and propagules source. Further, the surrounding natural forest was exhibited high tree species diversity $\left(\mathrm{H}^{\prime}=4.29, \mathrm{~N}=133\right)$. Thus, the seed and propagule sources and dispersal processes play important role in the natural regeneration during reclamation which needs to be considered.

Meanwhile, tree diversity indices at pre-mining sites of East Block were considered moderate $\left(H^{\prime}=2.80-2.76\right)$, due to previous forest fires and selective logging. Some of native tree species with high conservation and timber values recorded such as Borassodendron borneense, Eusideroxylon zwageri, Koompassia excelsa and Alstonia scholaris; edible fruit tree species such as Dimocarpus longan and Canarium asperum (Budiharta et al. 2020, data not shown). Further, some coal mine operators also provide in-situ conservation area (arboretum) which represents the existing natural forests in mining concession with many high conservation values of plants (Fiqa et al. 2019). It may become the source of valuable seeds and propagules for reclamation program. However, this study showed that those high conservation value species are not yet available spontaneously on both reclamation sites. It may due to the propagule barriers, the locations of reclamation sites were fragmented which separated by active main roads for coalmining operations. Therefore, intentional efforts by inserting seedlings of those valuable native species to the reclamation sites are suggested to conduct in order to strengthen the forest integrity, to replace the pioneers, and to accelerate the succession process.
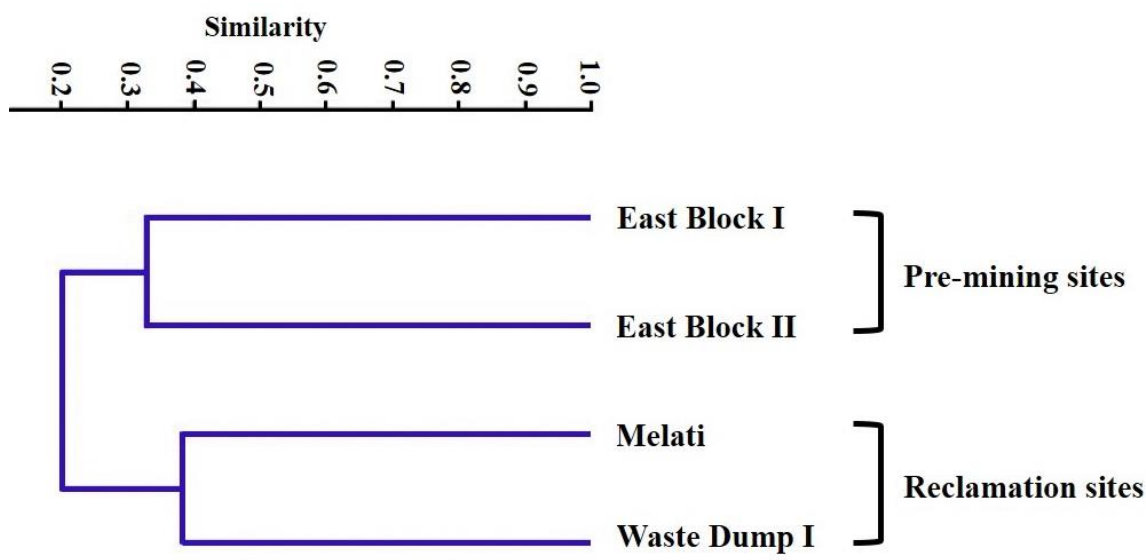

Figure 6. Dendrogram of clustering pattern based on spontaneous plant species composition on reclamation sites compared to premining sites 


\section{Association of micro-climates and soil conditions in affecting spontaneous plants recolonization}

The differences of site characteristics particularly the micro-climates and soil conditions, indeed affecting the establishment and growth of spontaneous plants on reclamation site. The spontaneous plant recolonization of post-mining reclamation sites was considered slow since the poor soil and environmental conditions in which not suitable for most of the plant species. Nevertheless, plants may adjust to local nutrient availability through changes in species composition, phenotypic plasticity, and local adaptation (Wright et al. 2011). From this study, it can be highlighted that more open canopy and greater light availability in the 9-y.o. reclamation site enables establishment of grasses and shrubs. Meanwhile, more diverse species of shrubs, herbaceous and ferns were associated to higher air humidity with moderate to high light intensity as shown in the 17-y.o. reclamation site. Local pioneers of Euphorbiaceae and Phyllantaceae as the species indicator of disturbances in secondary forest also well grown and dominated on both reclamation sites with open areas and high light intensity. Further, the patches of empty spaces on disturbed sites may become the opening window for alien species invasion and weeds, as IAS and some noxious weeds were identified successfully recolonized and dominated on both reclamation sites.

Edaphic or soil conditions may give a strong influence on vegetation productivity and produce considerable variation in nutrient cycling processes. Soil analysis revealed that both sites had very acidic $\mathrm{pH}<4.5$ (Table 4 ). High acidity in mine spoils was due to oxidation of residual elements of coal particularly iron sulfide such as pyrite $\left(\mathrm{FeS}_{2}\right)$ and to lesser extent pyrrhotite $\left(\mathrm{Fe}_{1-\mathrm{XS}}\right)$ (PozoAntonio et al. 2014). It constraint spontaneous revegetation, which hampers root-growth of plant, thus some plant species with high tolerance in acidic environment were dominated the area, such as IAS and noxious weeds. The soil ratio of $\mathrm{C} / \mathrm{N}$ was considered very low on both sites (Table 4), which means low availability of Carbon-organic (C) and macronutrient Nitrogen (N) which can be absorbed for plants. Nitrogen is an integral part of chlorophyll manufacture through photosynthesis and stimulates green leafy growth. The soil organic matters on both sites need further decomposition by microbial organisms to make it available for plants. However, due to high soil acidity beneficial root symbionts such as Rhizobium and arbuscular mycorrhizal fungi (AMF) as free-living $\mathrm{N}$-fixers and other microbes are also reduced in post-mine sites (Asmelash et al. 2016).

The other available soil macronutrients of phosphorus (P) was considered very low, but potassium (K) was very high on both reclamation sites (Table 4). Phosphorus supports the transfer of energy throughout the plant for root development and flowering whereas potassium is essential for photosynthesis and regulates many metabolic processes required for growth, fruit and seed development (Wright et al. 2011). Meanwhile, only small amount of micronutrients are required by plants such as Iron $(\mathrm{Fe})$ and manganese (Mn). This study showed that both micronutrients were considered very low to low in both reclamation sites (Table 4). Aluminum (Al) saturation was considered moderate (Table 4), which means it was good conditions for both reclamation sites, since the higher value of $\mathrm{Al}$ saturation will be toxic for plants. M. malabathricum is considered as Al hyper-accumulator species that grows in tropical acid soils (Patek-Mohd et al. 2018) therefore it became dominant in both reclamation sites.

Table 4. Comparison of soil conditions for spontaneous plant recolonization on two reclamation sites

\begin{tabular}{|c|c|c|c|}
\hline $\begin{array}{l}\text { Soil physico-chemical } \\
\text { characteristics }\end{array}$ & $\begin{array}{l}\text { Melati } \\
\text { (9-y.o. reclamation) }\end{array}$ & $\begin{array}{l}\text { Waste Dump I } \\
\text { (17-y.o. reclamation) }\end{array}$ & Criteria* $^{*}$ \\
\hline $\mathrm{pH}$ & $4.44 \pm 0.08$ & $4.70 \pm 0.05$ & $\mathrm{M}$ and $\mathrm{WDI}=$ very acidic \\
\hline $\mathrm{C}$ organic $(\% 0$ & $1.27 \pm 0.23$ & $1.04 \pm 0.31$ & $\mathrm{M}$ and $\mathrm{WDI}=$ low \\
\hline $\mathrm{N}$ total $(\%)$ & $0.11 \pm 0.07$ & $0.21 \pm 0.02$ & $\mathrm{M}=$ low, $\mathrm{WDI}=$ moderate \\
\hline $\mathrm{C} / \mathrm{N}$ ratio & $5.12 \pm 2.01$ & $5.91 \pm 1.76$ & $\mathrm{M}$ and $\mathrm{WDI}=$ low \\
\hline $\mathrm{P}_{2} \mathrm{O}_{5}$ Bray-1 (ppm) & $5.89 \pm 4.37$ & $8.27 \pm 0.68$ & $\mathrm{M}$ and $\mathrm{WDI}=$ very low \\
\hline $\mathrm{K}_{2} \mathrm{O} \mathrm{HCl}(\mathrm{ppm})$ & $98.89 \pm 3.33$ & $68.89 \pm 2.72$ & $\mathrm{M}$ and $\mathrm{WDI}=$ very high \\
\hline $\mathrm{Fe}(\mathrm{ppm})$ & $10.71 \pm 4.95$ & $1.92 \pm 1.10$ & $\mathrm{M}$ and $\mathrm{WDI}=$ very low \\
\hline $\mathrm{Mn}(\mathrm{ppm})$ & $6.25 \pm 0.19$ & $0.80 \pm 0.07$ & $\mathrm{M}=$ low, $\mathrm{WDI}=$ very low \\
\hline $\mathrm{K}^{+}($meq./100g) & $1.01 \pm 0.06$ & $0.83 \pm 0.29$ & $\mathrm{M}=$ very high, $\mathrm{WDI}=$ high \\
\hline $\mathrm{Na}^{+}($meq. $/ 100 \mathrm{~g})$ & $0.41 \pm 0.05$ & $0.39 \pm 0.06$ & $\mathrm{M}$ and $\mathrm{WDI}=$ moderate \\
\hline $\mathrm{Ca}^{2+}($ meq. $/ 100 \mathrm{~g})$ & $1.09 \pm 0.15$ & $1.48 \pm 0.66$ & $\mathrm{M}$ and $\mathrm{WDI}=$ low \\
\hline $\mathrm{Mg}^{2+}($ meq./100g) & $0.86 \pm 0.16$ & $0.85 \pm 0.30$ & $\mathrm{M}$ and $\mathrm{WDI}=$ low \\
\hline CEC (meq./100g) & $7.67 \pm 0.46$ & $12.27 \pm 5.17$ & $\mathrm{M}$ and $\mathrm{WDI}=$ low \\
\hline Base saturation $(\%)$ & $43.97 \pm 5.32$ & $29.97 \pm 3.14$ & $\mathrm{M}=$ moderate, $\mathrm{WDI}=\mathrm{low}$ \\
\hline $\mathrm{Al}$ saturation $(\%)$ & $20.37 \pm 3.84$ & $29.40 \pm 1.07$ & $\mathrm{M}$ and $\mathrm{WDI}=$ moderate \\
\hline Texture (clay/silt/sand ratio) & $25.29 / 26.95 / 47.76$ & $23.23 / 34.92 / 41.85$ & $\mathrm{M}=$ loam soil, $\mathrm{WDI}=$ sandy clay loam soil \\
\hline
\end{tabular}

Note: *Reference: Center for Soil and Agro-Climate Research (1983). Notes: M= Melati (9-y.o. reclamation), WDI= Waste Dump I (17y.o. reclamation) 
Further, the cation exchange capacity (CEC) on both reclamation sites were categorized as low, whilst base saturation (BS) value was low in the older site and moderate in the younger site (Table 4). Those values indicating that the available cations for plants were low for their development. Indeed, forest clearing and cultivation cause a drastic loss of CEC and cations (Zajicova and Chuman 2019) Soil texture analysis showed that the older sites have better soil texture (sandy clay loam) than the younger site (loam). Loamy soil was less porous, which makes the tree roots difficult to penetrate the soil substrates (Helliwell et al. 2019). According to all soil properties of both sites generally were categorized as poor soils therefore only adaptive plant species are able to strive and survive in this habitat; such as IAS, weeds, shrubs, grasses, herbs, and pioneers tree species, as reported in this study. Some inputs of management practices to improve the soil conditions are required.

\section{Evaluation of the succession progress and implications towards reclamation practices improvement}

Succession is a continuous process, these study findings suggests that the succession stages of both reclamation sites at ages 9 and 17 years were identified at the same stage, as plant establishment phase of early succession stage in transition to mid-succession stage. It was characterized by the establishment of rapidly growing plants which accumulate biomass and covering the site with high leaf surface area, and the existence of young or juvenile plants which face competition challenges. Nevertheless, the first wave of (planted) pioneer trees mortality have been indicated, also the accumulation of snags and logs, and the establishment of shade-tolerant species in the understory (Silvestrini and Dos Santos 2015). However, with 8 years old gap, the succession progress in Waste Dump I was also considered relatively older/latter than Melati Site. The spontaneous plant recolonization on both sites was found only in two layers i.e. understory and sapling; whilst pole and tree layers are not yet available. Both sites were dominated mostly by general saplings and understories species component of secondary tropical forest, but Waste Dump I was considered higher in number of plant species and density. It was also dominated by more shade-tolerant species such as shrubs, herbaceous and ferns in the understory. Further, the environmental condition in Waste Dump I has lower in light intensity, larger canopy coverage of planted pioneers, relatively similar soil nutrients but better soil texture than Melati Site. The decline of planted pioneer trees was also reported higher in Waste Dump I.

Some attributes of both abiotic and biotic factors influencing the establishment of spontaneous plants on reclamation sites include: (i) Space, include suitable soil substrates, nutrients availability and minimum threshold of heavy metal level for plants are required. (ii) Light, both excessive light or insufficient light for photosynthesis must be considered. (iii) Air temperature and moisture, optimum air temperature and sufficient air moisture near the soil surface are needed for seeds to most readily germinate and establish. (iv) Propagule/seed banks, due to the propagules limitation, recolonization processes may lead to novel species assemblies, including IAS and weeds. Further, traits affecting the dispersal, establishment abilities and invasiveness of the propagules are critical to the competitive status of a plant species in the community, particularly on disturbed sites (Lister 2010; Richardson and Rejmanek 2011; Lemke et al. 2012; Tischew et al. 2013).

The spontaneous plant recolonization of post-mining reclamation sites in this study was considered slow since the poor soil characteristics and environmental conditions in which not suitable for most of the plant species. However, some tolerant plant species have spread and established easily in these environments. Since the exposed surface of reclamation sites has lack of seed bank, so it was mostly recolonized by adjacent species. Hence; IAS, some weed species and pioneers of secondary forest species appeared to recolonized and dominated the area due to their adaptive features. Further, the presence of competing for vegetation, particularly IAS and noxious weeds which commonly occur on disturbed soil, can extend the establishment phase and slow down the succession progress, particularly for some native woody plants with slow growth rates. According to this comparative study's findings, some considerations for further reclamation practices improvement are suggested. It may become inputs for the mine operation management in improving the succession process of reclamation site, also as a reference for other reclamation activities in the tropics. Further periodic monitoring and evaluation of succession process need to be carried out continuously to manage the successional direction of the reclamation area.

\section{Inputs management for effective reclamation of post- coal mining}

Some inputs of management practices to improve the soil conditions of the reclamation site, include: (i) The acidic soil needs to be overcome by making proper drainage on sites, and adding alkaline materials such as calcite $\left(\mathrm{CaCO}_{3}\right)$, burnt lime $(\mathrm{CaO})$, slaked lime $\left[\mathrm{Ca}(\mathrm{OH})_{2}\right]$, dolomite $\left[\mathrm{CaMg}\left(\mathrm{CO}_{3}\right)_{2}\right]$, and slag $\left[\mathrm{CaSiO}_{3}\right]$, with various ability to neutralize the acidity; although it supposed to be done at the initial stage of reclamation (Pozo-Antonio et al. 2014). Low-grade of magnesia (MgO) may be an economically feasible alternative to lower the acidic soil also to stabilize the heavy metals from heavily contaminated soils (Pantazopoulou et al. 2020). (ii) The poor soils can be improved through the addition of organic amendments such as animal manures; crop residues (spoiled hay, straw, etc.); biosolids (sewage sludge); wastes from dairy, vegetable, fish, meat/carcasses and poultry from processing industries; wastes from paper mills, timber and paper products; peat; compost, etc. Animal manures and biosolids are good to improve soil aggregates with fertilizer value to supply $\mathrm{N}, \mathrm{P}$ and $\mathrm{K}$ for plants $(25 \%$ readily available). Whilst; yard waste, bark, and composts are good for soil conditioners mainly to improve soil properties by building soil organic matter (Larney and Angers 2012). Further, the application of pig manure and sewage sludge has been proved to be effective to activate 
microbial populations and activity in just after 5 years of application (Zornoza et al. 2010). (iii) Microbial bioinoculants contains beneficial microorganisms such as vesicular-arbuscular mycorrhiza (VAM), plant growthpromoting rhizobacteria (PGPR), Phosphate solubilizing microorganism (PSM), and blue-green algae, etc. can be applied to improve the soil fertility status and biological activities. It plays role in biomineralization of bound soil and decomposition to make nutrients available to their host plants and/or its surroundings. There is abundant scientific evidence to demonstrate that application of microbial bioinoculants package for soil reclamation of abandoned mine land by revegetation significantly improve soil attributes, increase above and belowground biodiversity, significantly improve tree/shrub seedlings survival, growth and establishment on moisture and nutrient stressed soils (Dash and Gupta 2011; Asmelash et al. 2016). Hence, it could help to facilitate soil reclamation on degraded lands.

Furthermore, the occurrences and dominance of IAS and noxious weeds on reclaimed area also suggested to be controlled since it may disrupt the successions process. Some relevant management strategies for post-coal-mining reclamation to reduce impacts of IAS and noxious weeds, include: (i) Promote education for operators to prevent the introduction and spreads of invasive species. Invasive species may be established from contaminated seeds and propagules carried on muddy equipment from infested areas, thus must be minimized. (ii) Detect and respond rapidly to and control populations of such species in a costeffective and environmentally manner. Timely mowing can be an effective strategy to prevent the seed set. Herbicides can be applied to weeds for control but often are ineffective over the long term. Biological control can be used by restoring competitors and natural enemies for long-term control of plant invaders (how effective? still questionable and debatable). (iii) Monitor the invasive species populations accurately and reliably, to monitor the direction of succession. (iv) Provide for restoration of native species (replacement) and habitat reconditions in ecosystems that have been invaded to strengthen the forest integrity and lower the associated habitat attributes from invasions of IAS. Adjusting the reclamation by planting more native tree species would aid in reducing the number and diversity of invasive plants. It also accelerates the succession progress fast forward to mid-succesion stage and thereafter to climax or late succession stage (Clewley et al. 2012; Lemke et al. 2012; Li et al. 2015, Myers and Cory 2017).

\section{ACKNOWLEDGEMENTS}

This study was sponsored by PT Indominco Mandiri (IMM), a subsidiary of PT Indo Tambangraya Megah (ITM) Tbk. in 2018. Great appreciation dedicated to the site management and staff of PT IMM for all the technical assistance and valuable discussions during the fieldwork. Sincere thanks addressed to the fieldwork team members of Purwodadi Botanic Garden i.e. Achmad Suef (plant identification), Achmad Muflichin, Albukorin, Purnomo, and Rika Yuni Riantini; also to Apriyono Rahadiantoro for helping authors in providing the map of study area.

\section{AUTHOR'S CONTRIBUTION}

All authors (L.H., T.T., S.B.) were contributed equally in this manuscript from conceptualization, designed the methodology, performed the fieldworks, analyzed the data, writing the draft manuscript, to the review and editing of the final manuscript.

\section{REFERENCES}

Angiosperm Phylogeny Group (APG IV). 2016. An update of the Angiosperm Phylogeny Group classification for the orders and families of flowering plants: APG IV. Bot J Linn Soc 181 (1): 1-20. DOI: $10.1111 /$ boj.12385.

Asmelash F, Bekele T, Birhane E. 2016. The potential role of arbuscular mycorrhizal fungi in the restoration of degraded lands. Front Microbiol 7: 1095. DOI: 10.3389/fmicb.2016.01095.

Bergeron A, Pellerin S. 2014. Pteridophytes as indicators of urban forest integrity. Ecol Indicators 38: 40-49. DOI: 10.1016/j.ecolind.2013.10.015.

Budiharta S, Meijaard E. 2014. State of Kalimantan's biodiversity. In: Resosudarmo BP, Imansyah MH, Napitupulu L (eds.) Development, Environment and the People of Kalimantan. Indonesian Regional Science Association (IRSA), Jakarta. [Indonesian]

Camino JPA. 2014. Comparative Allelopathy of Macaranga tanarius and Macaranga grandifolia Against The Agricultural Weeds Amaranthus spinosus, Corchorus olitorius, and Euphorbia heterophylla. [Thesis]. Natural Science and Mathematics Cluster, Ateneo de Davao University, Phillippines.

Center for Soil and Agro-Climate Research. 1983. Assessment criteria for chemical properties of soil. Center for Soil Research and Agroclimate, Bogor, Indonesia. [Indonesian]

Chen F, Yang Y, Mi J, Liu R, Hou H, Zhang S. 2019. Effects of vegetation pattern and spontaneous succession on remediation of potential toxic metal-polluted soil in mine dumps. Sustainability 11 (2): 397. DOI: 10.3390/su11020397.

Chia EJJ, Ooi1 ZY, Lua HK, Loo AHB, Ang WF, Ong KH, Wong KM. 2017. Glochidion obscurum B1. (Phyllanthaceae), a new record for Singapore. Nat Sing 10: 49-53.

Clewley GD, Eschen R, Shaw RH, Wright DJ. 2012. The effectiveness of classical biological control of invasive plants. J Appl Ecol 49: 12871295. DOI: 10.1111/j.1365-2664.2012.02209.x.

Dash S, Gupta N. 2011. Microbial bioinoculants and their role in plant growth and development. Intl J Biotech Mol Biol Res 2 (13): 232251. DOI: 10.5897/IJBMBRX11.005.

Dashora K. 2011. Nitrogen yielding plants: The pioneers of agriculture with a multipurpose. Am-Eur J Agron 4 (2): 34-37.

Department of Mineral and Energy East Kalimantan. 2013. Mining Statistic in East Kalimantan 2012. Department of Mineral and Energy East Kalimantan Province, Samarinda. [Indonesian]

Dwiki S. 2018. Development of environmental policy in Indonesia regarding mining industry in comparison with the United States and Australia: The lesson that can be learned. Evergreen 5 (2): 50-57.

Early R, Bradley BA, Dukes JS, et al. 2016. Global threats from invasive alien species in the twenty-first century and national response capacities. Nat Com 7: 12485. DOI: 10.1038/ncomms12485.

Fiqa AP, Fauziah, Lestari DA, Budiharta S. 2019. The importance of insitu conservation area in mining concession in preserving diversity, threatened and potential floras in East Kalimantan, Indonesia. Biodiversitas 20 (1): 198-210. DOI: 10.13057/biodiv/d200123.

Franke ME. 2016. Understanding Invasive Species Impacts on Reclaimed Surface-Mined Lands. [Thesis]. Virginia Polytechnic Institute and State University, Blacksburg, Virginia.

GISD (Global Invasive Species Database). 2019. Invasive alien species profile. http://www.iucngisd.org/gisd/.

Hagan DL, Jose S, Lin C-H. 2013. Allelopathic exudates of cogon grass (Imperata cylindrica): Implications for the performance of native pine 
savanna plant species in the Southeastern US. J Chem Ecol 39: 312322. DOI: 10.1007/s10886-013-0241-z.

Hammer Ø, Harper DAT, Ryan PD. 2001. PAST: Paleontological statistics software for education and data analysis. Palaeontol Elec 4 (1): $1-9$.

Hapsari L, Basith A, Novitasiah HR. 2014. Inventory of invasive plant species along the corridor of Kawah Ijen Nature Tourism Park, Banyuwangi, East Java. J Ind Tour Dev Std 2 (1): 1-9.

Hazarika P, Talukdar NC, Singh YP. 2006. Natural colonization of plan species on coal mine spoils at Tikak Colliery, Assam. Trop Ecol 47 (1): 37-46.

Helliwell JR, Sturrock CJ, Miller AJ, Whalley WR, Mooney SJ. 2019. The role of plant species and soil condition in the structural development of the rhizosphere. Plant Cell Environ 42: 1974-1986. DOI: $10.1111 /$ pce. 13529 .

Hossain MK, Anwar S, Nandi R. 2016. Allelopathic effects of Mikania cordata on forest and agricultural crops in Bangladesh. J For Res 27 (1): 155-159. DOI: $10.1007 / \mathrm{s} 11676-007-0060-6$.

Hu G, Zhang Z. 2013. Allelopathic effects of Chromolaena odorata on native and non-native invasive herbs. J Food Agr Env 11 (1): 878882.

ISC [Invasive Species Compendium]. 2019. ISC datasheet. https://www.cabi.org/ISC/datasheet/7641.

Kabrna M, Hendrychová M, Prach K. 2013. Establishment of target and invasive plant species on a reclaimed coal mining dump in relation to their occurrence in the surroundings. Intl J Mining Reclam Env 242249. DOI: $10.1080 / 17480930.2013 .820390$.

Karyati, Ipor IB, Jusoh I, Wasli ME. 2018. Tree stand floristic dynamics in secondary forests of different ages in Sarawak, Malaysia. Biodiversitas 1993: 767-773. DOI: 10.13057/biodiv/d190302.

Komara LL, Choesin DN, Syamsudin TS. 2016. Plant diversity after sixty years post-coal mining in East Kalimantan, Indonesia. Biodiversitas 17 (2): 531-538. DOI: $10.13057 /$ biodiv/d170220.

Larney FJ, Angers DA. 2012. The role of organic amendments in soil reclamation: A review. Can J Soil Sci 92: 19-38. DOI 10.4141/CJSS2010-064.

Lemke D, Schweitzer CJ, Tazisong IA, Wang Y, Brown JA. 2012 Invasion of a mined landscape: what habitat characteristics are influencing the occurrence of invasive plants? Intl J Mining Reclam Env 1-19. DOI: $10.1080 / 17480930.2012 .699215$

Lestari DA, Fiqa AP, Fauziah, Budiharta S. 2019. Growth evaluation of native tree species planted on post-coal mining reclamation site in East Kalimantan, Indonesia. Biodiversitas 20 (1): 134-143. DOI: 10.13057/biodiv/d200116

Li W, Luo J, Tian X, Chow WS, Sun Z, Zhang T, Peng S, Peng C. 2015. A new strategy for controlling invasive weeds: selecting valuable native plants to defeat them. Sci Rep 5: 11004, DOI: 10.1038/srep11004.

Lister D. 2010. An evaluation of factors influencing spontaneous vegetation succession in northern latitude disturbances: Assessment of natural recolonization of disturbances in Yukon. Mining and Petroleum Environment Research Group, MPERG 2010-6, Yukon, Canada.

Lowe S, Browne M, Boudjelas S, De Poorter M. 2000. 100 of the world's worst invasive alien species a selection from the global invasive species database. Published by The Invasive Species Specialist Group (ISSG) a specialist group of the Species Survival Commission (SSC) of the World Conservation Union (IUCN), Gland, Switzerland.

Ludwig JA, Reynolds JF. 1988. Statistical Ecology. John Wiley and Sons, New York.

Macdonald SE, Landhäusser SM, Skousen J. et al. 2015. Forest restoration following surface mining disturbance: challenges and solutions. New For 46: 703-732. DOI: 10.1007/s11056-015-9506-4.

McDonald T, Jonson J, Dixon KW. 2016. National standards for the practice of ecological restoration in Australia. Restor Ecol 24 (S1) S4-S32. DOI: 10.1111/rec.12359.

Makineci E, Gungoor BS, Kumbasli M. 2011. Natural plant revegetation on reclaimed coal mine landscapes in Agacli-Istanbul. Afr J Biotech 10 (16): 3248-3259. DOI: $10.5897 / \mathrm{AJB} 10.2499$.

Mossa J, James L. 2013. Impacts of mining on geomorphic systems. In: John FS (ed.). Treatise on Geomorphology. Academic Press, San Diego, USA

Mukhtar AS, Heriyanto NM. 2012. Plant succession at ex coal mine area in East Kalimantan. Jurnal Penelitian Hutan dan Konservasi Alam 9 (4): 341-350. [Indonesian]
Myers JH, Cory JS. 2017. Biological Control Agents: Invasive Species or Valuable Solutions?. In: Vilà M, Hulme $\mathrm{P}$ (eds) Impact of Biological Invasions on Ecosystem Services. Invading Nature-Springer Series in Invasion Ecology, Vol 12. Springer, Cham, Switzerland. DOI: 10.1007/978-3-319-45121-3_12.

Padmanaba M, Sheil D. 2014. Spread of the invasive alien species Piper aduncum via logging roads in Borneo. Trop Conserv Sci 7 (1): 35-44. DOI: $10.1177 / 194008291400700108$.

Pantazopoulou E, Ntinoudi E, Zouboulis AI, Mitrakas M, Yiannoulakis H, Zampetakis Th. 2020. Heavy metal stabilization of industrial solid wastes using low-grade magnesia, Portland and magnesia cement. J Mater Cycles Waste Manag. DOI: 10.1007/s10163-020-00985-9.

Patek-Mohd N-N, Abdu A, Jusop S, Abdul-Hamid H, Karim Md R, Nazrin M, Akbar M-H, Jamaluddin AS. 2018. Potentiality of Melastoma malabathricum as phytoremediators of soil contaminated with sewage sludge. Sci Agric 75 (1): 27-35. DOI: 10.1590/1678992X-2016-0002.

Pozo-Antonio S, Puente-Luna I, Lagüela-López S, Veiga-Ríos M. 2014. Techniques to correct and prevent acid mine drainage: A review. DYNA 81 (184): 73-80.

Richardson DM, Rejmanek M. 2011. Trees and shrub as invasive alien species - A global review. Divers Distrib 17: 788-809. DOI: 10.1111/j.1472-4642.2011.00782.x.

Robiansyah I, Purnomo DW. 2013. Effects of road on understory plant diversity and its habitat in corridor of Halimun Salak National Park, West Java. Jurnal Biologi Indonesia 9 (2): 183-197. [Indonesian].

Schladweiler BK. 2018. 40 years of the Surface Mining Control and Reclamation Act (SMCRA): what have we learned in the State of Wyoming. Intl J Coal Sci Technol 5: 3-7. DOI: 10.1007/s40789-0180193-6.

SEAMEO BIOTROP (Southeast Asian Regional Centre for Tropical Biology). 2019. Invasive alien species collection. SEAMEO BIOTROP, Bogor.

Sein CC, Mitlöhner R. 2011 Acacia mangium Willd: ecology and silviculture in Vietnam. CIFOR, Bogor, Indonesia.

Sher Z, Hussain F, Badshah L. 2014. Allelopathic potentials of Mallotus phillippinensis Muell. Euphorbiaceae. Pak J Bot 46 (6): 2057-2061

Silva VL, Mehltreter K, Schmitt JL. 2018. Ferns as potential ecological indicators of edge effects in two types of Mexican forests. Ecol Indicat 93: 669-676. DOI: 10.1016/j.ecolind.2018.05.029.

Silvestrini M, Dos Santos FA. 2015. Variation in the population structure between a natural and a human-modified forest for a pioneer tropical tree species not restricted to large gaps. Ecol Evol 5 (12): 2420-2432. DOI: $10.1002 /$ ece 3.1528 .

Slik JWF, Keßler PJA, van Welzen PC. 2003. Macaranga and Mallotus species (Euphorbiaceae) as indicators for disturbance in the mixed lowland dipterocarp forest of East Kalimantan (Indonesia). Ecol Indicat 2: 311-324.

Soendjoto MA, Dharmono, Mahrudin, Riefani MK, Triwibowo D. 2014. Plant richness after revegetation on the reclaimed coal mine land of PT. Adaro Indonesia, South Kalimantan. Jurnal Manajemen Hutan Tropika 20 (3): 142-150.

Su Y, Huang L, Wang Z, Wang T. 2018. Comparative chloroplast genomics between the invasive weed Mikania micrantha and its indigenous congener Mikania cordata: Structure variation, identification of highly divergent regions, divergence time estimation, and phylogenetic analysis. Mol Phylogenet Evol 126: 181-195. DOI: 10.1016/j.ympev.2018.04.015.

Tischew S, Baasch A, Grunert H, Kirmer A. 2013. How to develop native plant communities in heavily altered ecosystems: examples from large-scale surface mining in Germany. Appl Veg Sci 1-14. DOI: 10.1111/avsc. 12078 .

Trimanto, Hapsari L. 2016. Botanical survey in thirteen montane forests of Bawean Island Nature Reserve, East Java Indonesia: Flora diversity, conservation status, and bioprospecting. Biodiversitas 17 (2): 832-846. DOI: $10.13057 /$ biodiv/d170261

Tripathi N, Singh RS, Chaulya SK. 2012. Dump stability and soil fertility of a coal mine spoil in Indian dry tropical environment: A long-term study. Env Manag 50: 695-706. DOI: 10.1007/s00267-012-9908-4.

USDA-NRCS (United States Department of Agriculture Natural Resources Conservation Service). 2019. Federal noxious weeds list. https://plants.usda.gov/java/noxious.

Valladares F, Laanisto L, Niinemets Ü, Zavala MA. 2016. Shedding light on shade: ecological perspectives of understorey plant life. Plant Ecol Divers 9 (3): 237-251. DOI: 10.1080/17550874.2016.1210262. 
Wright SJ, Yavitt JB, Wurzburger N, Turner BL, Tanner EVJ, Sayer EJ, Santiago LS, Kaspari M, Hedin LO, Harms KE, Garcia MN, Corre MD. 2011. Potassium, phosphorus, or nitrogen limit root allocation, tree growth, or litter production in a lowland tropical forest. Ecology 92 (8): $1616-1625$. DOI: $10.1890 / 10-1558.1$.

Yusuf M, Arisoesilaningsih E. 2017. Exotic plant species attack revegetation plants in post-coal mining areas. AIP Conf Proc of 8th International Conference on Global Resource Conservation. 1908, 040002-1-040002-5. DOI: 10.1063/1.
Zajicova K, Chuman T. 2019. Effect of land use on soil chemical properties after 190 years of forest to agricultural land conversion. Soil Water Res 14: 121-131. DOI: 10.17221/5/2018-SWR.

Zornoza R, Faz Á, Carmona DM, BüYükkiliç A, Kabas S, MartínezMartínez S, Acosta J. 2010. Long-term effects of mine soil reclamation using different amendments on microbial and biochemical properties. 
Table S1. Spontaneous plant species list at reclamation sites: Melati site (9-y.o.) and Waste Dump I (17 y.o) in East Kalimantan

\section{SITE MELATI (9-y.o. reclamation)}

\section{Acanthaceae}

Asystasia gangetica*

Rungia sp.

Anacardiaceae

Anacardium occidentale

Aspleniaceae

Asplenium nidus

Asteraceae

Mikania cordata**

Chromolaena odorata*

Cyperaceae

Scleria scrobiculata

Davalliacea

Davallia denticulata

Dilleniaceae

Tetracera scandens

Euphorbiaceae

Glochidion littorale

Glochidion obscurum

Homalanthus populneus
Mallotus japonicus
Mallotus dispar
Phyllantaceae
Phyllanthus niruri
Phyllanthus urinaria
Hypericaceae
Cratoxylum sumatranum
Lamiaceae
Clerodendrum laevifolium
Callicarpa pentandra
Hyptis capitata
Vitex pinnata
Callicarpa longifolia
Leguminosae
Senna siamea
Acacia mangium
Senna siamea
Centrosema pubescens

Homalanthus populneus

Mallotus japonicus

Phyllanthus niruri

Phyllanthus urinaria

Hypericaceae

Cratoxylum sumatranum

Lamiaceae

Callicarpa pentandra

Hyptis capitato

Vitex pinnata

Leguminosae

Senna siamea

Senna siamea

Centrosema pubescens

\author{
Mimosa pudica \\ Lygodiaceae \\ Lygodium circinatum \\ Lygodium sp. \\ Melastomaceae \\ Clidemia hirta* \\ Melastoma malabathricum* \\ Pternandra galeata \\ Nephrolepidaceae \\ Nephrolepis exaltata \\ Piperaceae \\ Piper aduncum* \\ Poaceae \\ Axonopus compressus* \\ Oplismenus cf. burmannii \\ Poaceae \\ Polytrias indica* \\ Primulaceae \\ Embelia ribes
}

\author{
Rosaceae \\ Rubus sp. \\ Rubiaceae \\ Canthium glabrum \\ Rutaceae \\ Melicope glabra \\ Sapindaceae \\ Allophylus cobbe \\ Guioa pleuropteris \\ Smilacaceae \\ Smilax gigantea \\ Thelypteridaceae \\ Christella dentata \\ Vitaceae \\ Leea angulata \\ Zingiberaceae \\ Etlingiera sp. \\ Plagiostachys sp.
}

\section{SITE WASTE DUMP I ( 17-y.o. reclamation)}

$\begin{array}{ll}\text { Acanthaceae } & \text { Dilleniaceae } \\ \text { Asystasia gangetica* } & \text { Tetracera scandens } \\ \text { Anacardiaceae } & \text { Euphorbiaceae } \\ \text { Dracontomelon dao } & \text { Macaranga gigantea } \\ \text { Annonaceae } & \text { Macaranga tanarius } \\ \text { Maasia glauca } & \text { Macaranga triloba } \\ \text { Uvaria } \text { sp. } & \text { Mallotus japonicus } \\ \text { Apocynaceae } & \text { Hypericaceae } \\ \text { Gymnema } \text { sp. } & \text { Cratoxylum sumatranum } \\ \text { Araceae } & \text { Hypoxidaceae } \\ \text { Alocasia princeps } & \text { Curculigo } \text { orchioides } \\ \text { Araliaceae } & \text { Lamiaceae } \\ \text { Schefflera } \text { elliptica } & \text { Callicarpa longifolia } \\ \text { Aspleniaceae } & \text { Lauraceae } \\ \text { Asplenium nidus } & \text { Beilschmiedia } \text { sp. } \\ \text { Compositae } & \text { Leguminosae } \\ \text { Blumea lacera } & \text { Acacia mangium } \\ \text { Chromolaena } \text { odorata* } & \text { Leucaena } \text { sp. } \\ \text { Mikania cordata** } & \text { Senna } \text { siamea } \\ \text { Vernonia arborea } & \text { Lygodiaceae } \\ \text { Cyperaceae } & \text { Lygodium } \text { circinatum } \\ \text { Scleria scrobiculata } & \text { Malvaceae } \\ \end{array}$

Urena lobata

Melastomaceae

Clidemia hirta*

Melastoma malabathricum**

Pternandra galeata

Moraceae

Ficus septica

Nephrolepidaceae

Nephrolepis exaltata

Passifloraceae

Passiflora foetida*

Phyllantaceae

Bridelia stipularis

Glochidion littorale

Glochidion obscurum

Homalanthus populneus

Phyllanthus urinaria

Piperaceae

Piper aduncum*

Poaceae

Axonopus compressus*

Imperata cylindrica $*, * *$
Oplismenus cf. burmanni

Oplismenus sp.

Polytrias indica*

Primulaceae

Embelia ribes

Rubiaceae

Canthium glabrum

Rutaceae

Clausena sp.

Melicope glabra

Melicope sp.

Sapindaceae

Guioa pleuropteris

Solanaceae

Solanum sp.

Vitaceae

Leea angulata

Zingiberaceae

Alpinia sp.

Note: $*=$ invasive alien species, $* *=$ noxious weed species 